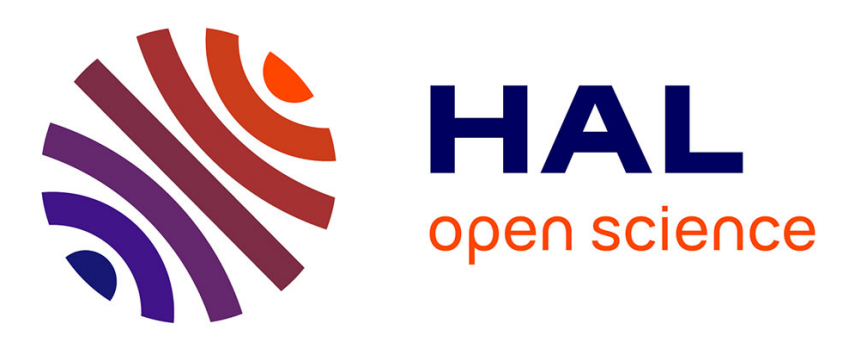

\title{
THE REFORM OF THE JUDICIAL SYSTEM IN UKRAINE IN 2014-2019: MAJOR ACHIEVEMENTS
}

Anatoliy Kostruba

\section{To cite this version:}

Anatoliy Kostruba. THE REFORM OF THE JUDICIAL SYSTEM IN UKRAINE IN 2014-2019: MAJOR ACHIEVEMENTS. hal-02888396

\section{HAL Id: hal-02888396 https://hal.science/hal-02888396}

Submitted on 3 Jul 2020

HAL is a multi-disciplinary open access archive for the deposit and dissemination of scientific research documents, whether they are published or not. The documents may come from teaching and research institutions in France or abroad, or from public or private research centers.
L'archive ouverte pluridisciplinaire HAL, est destinée au dépôt et à la diffusion de documents scientifiques de niveau recherche, publiés ou non, émanant des établissements d'enseignement et de recherche français ou étrangers, des laboratoires publics ou privés. 


\title{
THE REFORM OF THE JUDICIAL SYSTEM IN UKRAINE IN 2014-2019: MAJOR ACHIEVEMENTS
}

\author{
РЕФОРМА СУДОВОЇ СИСТЕМИ В УКРАЇНІ 2014-2019 років: \\ ОСНОВНІ ДОСЯГНЕННЯ
}

Kostruba A.V., Doctor of Law, Professor, Professor of Civil Law Department Vasyl Stefanyk Precarpathian National University

The article provides an analysis of the current state of the procedural legislation of Ukraine in the context of the judicial system reform carried out in 2014-2019. The drastic changes in this direction, which began with the tragic events in the life of Ukraine in 2014, radically reversed the three components of national justice - judicial system, status of judges and legal procedure. The key issue of the judicial reform in Ukraine is the implementation of the principles of the organization and administration of justice, the main of which is the supremacy of the law.

The essential principle in terms of the strategic vision of the key results of the judicial reform in Ukraine was the improvement of such principles as political and economic independence of justice. In accordance with constitutional amendments, a reauthorization took place between the High Qualification Commission of Judges of Ukraine and the new constitutional body - the High Council of Justice. The power to review disciplinary cases against all judges, taking decisions on temporary suspension of judges from the justice fall within the competence of the latter. The Higher Qualification Commission of Judges of Ukraine is solely responsible for selection of judges, qualification assessments, holding competitions to fill the vacancy for judges.

The second principle of the organization and implementation of the judicial power in Ukraine was the principle of accessibility of justice, which is traditionally viewed as a lack of excessive judicial expenses, lack of judicial corruption, complex judicial procedures and excessive length of the judicial process. The primary change reflected in all procedural codes is the introduction of effective protection of rights the rights of a person. Particular attention is paid to ensuring the activities of the Supreme Court and implementing mechanisms that ensure the unity of law enforcement practice within the framework of a unified cassation proceedings.

An important step in the implementation of the justice reform was the reformation of legal institutions related to the judicial system (advocacy, court enforcement action, reform of legal education, etc.).

Key words: judicial reform, Supreme Court, judicial procedures, judicial authorities, constitutional reform, procedyral codofocation.

України в контексті проведеної в 2014-2019 роках реформи судоустрою. Ключове питання судової реформи в Україні полягає в реалізації принципів організації і здійснення правосуддя, основнім з яких є верховенство права. Істотним з точки зору стратегічного бачення ключових результатів судової реформи в Україні стало вдосконалення таких принципів, як політична і економическая незалежність правосуддя. Внесено зміни щодо основ конституційно-правового статусу судді, зокрема підвищені вікові і професійні цензи до кандидатів на посаду судді, запроваджено конкурсний принцип призначення судді на посаду, уточнені і посилені гарантії незалежності та недоторканності суддів. 3 метою забезпечення стандартів незмінюваність суддів скасований інститут «призначення судді на посаду вперше» і передбачено, що судді обіймати посади безстроково.

Відповідно до конституційних змін відбувся перерозподіл повноважень між Вищою кваліфікаційною комісією суддів України та новим конституційним органом - Вищою радою правосуддя. До компетенції останнього належать, зокрема, повноваження з розгляду дисциплінарних справ щодо всіх суддів, прийняття рішень про тимчасове відсторонення суддів від правосуддя тощо.

Другим принципом організації та здійснення судової влади в Україні став принцип доступності правосуддя, який традиційно розглядається як відсутність надмірності в судові витрати, відсутність судової корупції, складних судових процедур і надмірної тривалості судового процесу. У діючих процесуальних кодексах імплементовані зміни до Конституції України щодо представництва інтересів осіб в судовому процесі адвокатом. Особливу увагу приділено забезпеченню діяльності Верховного Суду і створення механізмів, які обеспечіавют єдність правозастосовчої практики в рамках єдиного касаційного провадження.

Важливим кроком в реалізації реформи правосуддя стало рефрормування суміжних, до судоустрою, правових інститутів (адвокатура, виконавче провадження, реформа юридичної освіти та ін).

Ключові слова: судова реформа, Верховний Суд, судові процедури, судові органи, процесуальна кодифікація, конституційна реформа.

Introduction. Despite the fact that the Constitution of Ukraine declares the legal status of the state where human rights and freedoms and their guarantees determine the content and focus of its activity, the previous system of justice was not able to fulfill its tasks to ensure the rule of law in the activity of state. To the best of our belief, the main factors of this situation were the prevalence of corruption in the sphere of justice, the perpetual dependence of judges on executive and legislative branches of government, as well as the lack of unity and consistency in litigation practice.

Recent research and publications analysis. Recently, a number of scientific works have been published on the problem of judicial system organization. Therefore, development of procedural legislation and management of judicial bodies activity are the key issues addressed in the works of Orlov B.M., Zahartsev S.N., Abova T.E., Fara T.V., Husarov K.V., Komarov V.V., Shtefan M.Y. etc. The purpose of this article is to examine ways to solve the key challenges of the judicial system and procedure expressed in efficient implementation of the rule of law, access to justice and independence of the court from political components of the state administration process.
Disscussions. After the end of 2013 and the beginning of 2014, judicial reform was one of the most anticipated reforms in society, since a fair, unbiased and objective court is an important guarantee of the effective fight against corruption, attraction of investments to Ukraine and proper level of ensuring the rights and freedoms of every citizen.

The drastic changes in this direction, which began with the tragic events in the life of Ukraine in 2014, radically reversed the three components of national justice - judicial system, status of judges and legal procedure. The changes also affected all main aspects of the activity of courts and judges principles of the state judicial system, court system and its powers, course of litigation, mechanism for selecting judges, grounds for their responsibility, foundations of judicial selfgovernment.

The first stage of the relevant changes is related to adoption of the Law of Ukraine on the Restoration of Trust in the Judiciary in Ukraine dated 08 of April 2014, which determined the legal and organizational basis for conducting a special inspection of judges as a temporary stepped up measure aimed at increasing the authority of the judiciary in 
Ukraine and the trust of citizens to the judicial branch, as well as restoration of law and justice [1].

According to the indicated legal act, the inspection of judges was meant to establish facts of the judges making decisions regarding restriction of the citizens' rights to hold meetings, rallies, processions, demonstrations concerning persons participated in mass protests in late 2013 - early 2014, etc.

An important step in the implementation of justice reform was to introduce the Strategy for reforming judicial system and proceedings and related legal institutions for 20152020 approved by the Decree of the President of Ukraine in 2015 [2]. This work resulted in adoption of the Law of Ukraine on Ensuring the Right to a Fair Trial in 2015 [3].

One of the main tasks that is solved along with the entry into force of this law is to ensure the independence, impartiality and objectiveness of judges. In view of this, the procedure for appointing judges to posts and transferring them to other courts has been improved, and maximum transparency and publicity of these procedures has been ensured. In particular, personnel appointments of judges are carried out exclusively on a competitive basis. Herewith, Verkhovna Rada of Ukraine and the President of Ukraine perform only ceremonial functions and have no influence on the adoption of personnel decisions.

The final stage of the judiciary reform was the introduction of amendments to the Constitution of Ukraine in order to deprive judges of political influence, ensure effective judicial self-government, and minimize corruption. To develop agreed and comprehensive constitutional amendments involving representatives of various political forces, the public, national and international experts into this work, the President of Ukraine, by Decree No. 119 as of 3 of March 2015, appointed the Constitutional Commission, which prepared proposals for amendments related to justice to the Constitution of Ukraine [4]

As a result, on 02 of June 2016, the Law of Ukraine on Amending the Constitution of Ukraine (regarding justice) was adopted [5]. Amendments to the Constitution of Ukraine (regarding justice) are clearly aimed at ensuring the independence of the judiciary, stepping up requirements and professional standards for the judiciary, limiting the immunity of judges to functional, optimizing the judicial system, ensuring the institutional capacity of the prosecutor's office, the bar and the execution of judgment system.

The law revised the appointment of judges by the President of Ukraine as advised by the High Council of Justice, as well as ensuring the ceremonial role of the head of state in this process. The authority to relieve judges and transfer them from one court to another was delegated to the High Council of Justice.

Amendments were made regarding foundations of the constitutional and legal status of judges, particularly, age and professional qualifications for candidates for the post of judge were raised, competitive principle for appointing a judge to the post was introduced, and guarantees for the independence and integrity of judges were clarified and strengthened. To enforce the standard of irremovability of judges, the institution of "appointing a judge for the first time" was canceled and it was stipulated that judges should hold office indefinitely.

From then on, in order to immediately start the implementation of new provisions of the Constitution of Ukraine regarding justice and to continue the implementation of the judicial reform scheduled stages, amendments were made to the relevant laws of Ukraine, particularly to the Law of Ukraine on the Judiciary and the Status of Judges [6].

In general, amendments to the judiciary and related legal institutions were as follows:

\section{On the judiciary:}

1. Legal status foundations, procedure for formation and activity, as well as powers of the High Council of Justice as the body responsible for formation of a righteous and highly professional judicature were determined.

In accordance with constitutional amendments, a reauthorization took place between the High Qualification Commission of Judges of Ukraine and the new constitutional body - the High Council of Justice. Particularly, the power to review disciplinary cases against all judges, taking decisions on temporary suspension of judges from the justice, etc. fall within the competence of the latter [7].

The Higher Qualification Commission of Judges of Ukraine is solely responsible for selection of judges, qualification assessments, holding competitions to fill the vacancy for judges and judicial education.

2. The judiciary was updated and anti-corruption measures were introduced. Improved requirements for the content of a judicial record allow to collect the necessary information and data for proper qualification assessment according to all criteria provided by law. The possibility of career progression of a judge and obtaining a higher official salary solely based on the results of a qualification assessment was reinforced.

3 . The institute of functional immunity of the judge was laid.

The nature of judicial immunity in the delivery of justice lies in the prohibition of criminal prosecution of a judge for his/her legal position specified in a court decision, since the existence of such position rules out independence and impartiality of the judge.

As of today, it is stipulated that a judge cannot be held accountable for a court decision made by his/her, with the exception of a crime or disciplinary offense. Regarding actions not related to the performance of judicial functions, judges shall bear legal responsibility on general terms.

The Law of Ukraine on the Judiciary and the Status of Judges stipulates that a judge may be detained, kept in custody or under arrest until a court conviction is delivered without such consent if he/she has been detained during or immediately after the commission of a grave or especially grave crime. In addition, a judge detained on suspicion of committing an act for which criminal or administrative liability has been established shall be immediately dismissed [6].

4. Besides, in accordance with the provisions of the Law of Ukraine on the Judiciary and the Status of Judges, the judicial system has been optimized. It is determined that the judicial system is composed of local courts, courts of appeal and the Supreme Court. The highest court in the judicial system is the Supreme Court. The Supreme Court consists of no more than two hundred judges, which is half as much as the total number of judges of the courts of cassation and the Supreme Court of Ukraine before the reform. The Supreme Court has five structural units: Grand Chamber of the Supreme Court, Cassation Administrative Court, Cassation Court, Cassation Criminal Court, Civil Cassation Court.

To consider certain categories of cases in the judicial system, there are specialized higher courts (particularly, the High AntiCorruption Court and the Intellectual Property High Court.

On judicial procedures

1. In order to effectively exercise the right to a fair trial in Ukraine, in addition to institutional changes, systemic changes to the procedural legislation of Ukraine were carried out during 2017-2018. These changes contribute to clearing obstacles, among which there is an insufficient level of unity and consistency of law enforcement practice, inconsistency in the delimitation of the courts jurisdiction etc [8].

2 . The primary change reflected in all procedural codes is the introduction of effective protection of rights the rights of a person. Particularly, this norm is enshrined in article 5 of the Code of Administrative Procedure of Ukraine, part 2 of which specifies the following: "... protection of violated rights, freedoms or interests of a person who has applied to a court may be carried out by a court in another way not contradicting the law and providing effective protection of rights, freedoms and interests of a person and citizen, 
other parties in public law relations from violations by bodies of state power". Similar provisions are contained in other codified procedural acts [8].

3. Particular attention is paid to ensuring the activities of the Supreme Court and implementing mechanisms that ensure the unity of law enforcement practice within the framework of a unified cassation proceedings.

Thus, a court decision on particular case shall be reviewed in the manned set by the Supreme Court under the relevant complaint only once. Herewith, the Supreme Court may act as part of the board, chamber, joint chamber of the relevant cassation court, the Grand Chamber of the Supreme Court. If the board agrees with the practice of law enforcement in such legal relations that occurs in decisions of another board within the same chamber, another chamber of the same cassation court or another court of cassation, such board may submit the case to the chamber of which this board is a member, joint chamber of the respective cassation court, or the Grand Chamber of the Supreme Court, respectively.

In this case, the decision on the results of cassation proceedings shall be taken by the chamber, joint chamber of the respective cassation court or the Grand Chamber of the Supreme Court.
4. The current procedural codes have also implemented amendments to the Constitution of Ukraine regarding representation of persons in a law suit by a lawyer, excluding representation in court on labor disputes, disputes on the protection of social rights, regarding elections and referenda, in minor disputes, as well as regarding the representation of minors and persons recognized by the court as incompetent or whose capacity is limited.

Conclussions. The foregoing indicates the following. Nowadays, there is a mainstreaming of the court in the development of a democratic society, which updates the need to find proper means aimed at improving the judicial work, and increasing its effectiveness and openness. Work in this direction is of particular importance for the postSoviet countries, since the quality of judicial proceedings is a guarantee of democratic transformations in the social, political and economic spheres.

We can observe the process of an open and honest dialogue creation between the judiciary and the public. Transparency of judicial procedures and openness of the judicial work results have become a key in the integrity of a judge during delivery of justice, and a criterion for increasing public confidence in the state judiciary.

\section{REFERENCES}

1. Про відновлення довіри до судової влади в Україні: Закон України від 8 квітня 2014 р. № 1188-VII / Верховна Рада України. Голос України. 2014. 10 квітня. № 70-71.

2. Про Стратегію реформування судоустрою, судочинства та суміжних правових інститутів на 2015 - 2020 роки: Указ Президента України від 20 травня 2015 р. № 276/2015 / Президент України. URL: https://zakon.rada.gov.ua/laws/show/276/2015?lang=en/ (дата звернення 17. 04. 2020).

3. Про забезпечення права на справедливий суд: Закон України від 12 лютого 2015 р. № 192-VIII / Верховна Рада України. URL: https://zakon.rada.gov.ua/laws/show/192-19 (дата звернення 17. 04. 2020).

4. Про Конституційну комісію: Указ Президента України від 3 березня 2015 р. № 119/2015 / Президент України. URL: https://zakon5. rada.gov.ua/laws/show/119/2015 (дата звернення 17. 04. 2020).

5. Про внесення змін до Конституції України (щодо судочинства) від 2 червня 2016 р. № 1401-VIII / Верховна Рада України. URL: https://zakon.rada.gov.ua/laws/show/1401-19 (дата звернення 17. 04. 2020).

6. Про судоустрій і статус суддів: Закон України від 2 червня 2016 р. № 1402-VIII / Верховна Рада України. URL: https://zakon.rada. gov.ua/laws/show/1402-19 (дата звернення 17. 04. 2020).

7. Про Вищу ради правосуддя: Закон України від 21 грудня 2016 р. № 1798-VIII / Верховна Рада України. URL: https://zakon.rada.gov. ua/laws/show/1798-19 (дата звернення 17. 04. 2020).

8. Про внесення змін до Господарського процесуального кодексу України, Цивільного процесуального кодексу України, Кодекса административного судочинства України та інших законодавчих актів: Закон України від 3 жовтня 2017 р. №2171-VIII / Bepховна Рада України. URL: https://zakon.rada.gov.ua/laws/show/2147-19\#n2972 (дата звернення 17. 04. 2020). 